\title{
Extreme Weather and Climate Events and Their Impacts on Island Countries in the Western Pacific: Cyclones, Floods and Droughts
}

\author{
Yuriy Kuleshov1,2,3,4, Simon McGree,,2, David Jones', Andrew Charles1, Andrew Cottrill1, \\ Bipen Prakash', Terry Atalifo5, Salesa Nihmei ${ }^{6}$, Fata Lagomauitumua Sunny K. Seuseu ${ }^{7}$ \\ ${ }^{1}$ National Climate Centre, Bureau of Meteorology, Melbourne, Australia \\ ${ }^{2}$ School of Mathematical and Geospatial Sciences, Royal Melbourne Institute of Technology (RMIT) University, \\ Melbourne, Australia \\ ${ }^{3}$ Faculty of Sciences, Engineering and Technology, Swinburne University of Technology, Melbourne, Australia \\ ${ }^{4}$ Department of Mathematics and Statistics, The University of Melbourne, Melbourne, Australia \\ ${ }^{5}$ Fiji Meteorological Service, Nadi Airport, Fiji \\ ${ }^{6}$ Secretariat of the Pacific Regional Environment Programme (SPREP), Apia, Samoa \\ ${ }^{7}$ Samoa Meteorology Division, Ministry of Natural Resources and Environment, Apia, Samoa \\ Email: y.kuleshov@bom.gov.au
}

Received 25 September 2014; revised 26 October 2014; accepted 7 November 2014

Copyright (C) 2014 by authors and Scientific Research Publishing Inc.

This work is licensed under the Creative Commons Attribution International License (CC BY).

http://creativecommons.org/licenses/by/4.0/

(c) (i) Open Access

\section{Abstract}

Increases in the frequency of extreme weather and climate events and the severity of their impacts on the natural environment and society have been observed across the globe in recent decades. In addition to natural climate variability and greenhouse-induced climate change, extreme weather and climate events produce the most pronounced impacts. In this paper, the climate of three island countries in the Western Pacific: Fiji, Samoa and Tuvalu, has been analysed. Warming trends in annual average maximum and minimum temperatures since the 1950 s have been identified, in line with the global warming trend. We present recent examples of extreme weather and climate events and their impacts on the island countries in the Western Pacific: the 2011 drought in Tuvalu, the 2012 floods in Fiji and a tropical cyclone, Evan, which devastated Samoa and Fiji in December 2012. We also relate occurrences of the extreme weather and climate events to phases of the El Niño-Southern Oscillation (ENSO) phenomenon. The impacts of such natural disasters on the countries are severe and the costs of damage are astronomical. In some cases, climate extremes affect countries to such an extent that governments declare a national state of emergency, as occurred in Tuvalu in $\mathbf{2 0 1 1}$ due to the severe drought's impact on water resources. The projected increase in the frequency of weather and climate extremes is one of the expected conse- 
quences of the observed increase in anthropogenic greenhouse gas concentration and will likely have even stronger negative impacts on the natural environment and society in the future. This should be taken into consideration by authorities of Pacific Island Countries and aid donors when developing strategies to adapt to the increasing risk of climate extremes. Here we demonstrate that the modern science of seasonal climate prediction is well developed, with current dynamical climate models being able to provide skilful predictions of regional rainfall two-three months in advance. The dynamic climate model-based forecast products are now disseminated to the National Meteorological Services of 15 island countries in the Western Pacific through a range of web-based information tools. We conclude with confidence that seasonal climate prediction is an effective solution at the regional level to provide governments and local communities of island nations in the Western Pacific with valuable assistance for informed decision making for adaptation to climate variability and change.

\section{Keywords}

Extreme Weather and Climate Events, Western Pacific, Cyclones, Floods, Droughts

\section{Introduction}

Increases in the frequency of extreme weather and climate events and in the severity of their impacts on the natural environment and society have been observed across the globe in recent decades [1] [2]. In combination with natural climate variability and greenhouse-induced climate change, extreme weather and climate events produce the most pronounced impacts. Not surprisingly, the impacts are most felt in the least developed countries, especially small island developing states which have limited adaptive capacity. In this paper, we present examples of impacts due to extreme weather and climate events which have recently occurred in three Pacific Island Countries: Fiji, Samoa and Tuvalu, and have caused major economic and social disruption in these countries.

Tropical cyclones, floods and droughts are the most destructive severe weather and climate extreme events which affect countries in the Western Pacific. In this region, floods are typically associated with tropical disturbances and droughts are usually related to the El Niño-Southern Oscillation (ENSO). The ENSO is a large-scale climate phenomenon that occurs across the tropical Pacific Ocean and has two distinctly different phases: warm (El Niño) and cold (La Niña). There is also a neutral phase which is a transition mode from the ENSO warm phase to its cold phase and vice versa. Relationship between the ENSO and tropical cyclone activity in the Western Pacific (e.g. [3] [4]) and rainfall variability in Australia (e.g. [5]) are well understood and described in the literature. On the other hand, until recent research conducted under the Pacific Climate Change Science Program [6], there were only a few studies which documented climatic conditions in the Western Pacific islands and the ENSO impacts on regional climate variability. Impacts of weather and climate extremes on the environment and society in this region are even less well documented. Thus, this motivated us to describe impacts of extreme weather events on island countries in the Western Pacific. Presenting a few case studies, this paper describes some of the impacts caused by cyclones, floods and droughts, along with establishing relationships between occurrences of climate extremes and the ENSO phases.

Analysing historical records from the archives of the National Meteorological Services (NMSs) of Fiji, Samoa and Tuvalu for the past few decades, we identified a number of severe weather and climate extreme events and traced their relationship to phases of the ENSO. Rainfall distribution is closely related to the ENSO variability, and the position and intensity of the key climate features namely the Intertropical Convergence Zone (ITCZ), West Pacific Monsoon (WPM) and South Pacific Convergence Zone (SPCZ; [6]). Therefore the impact of severe weather and climate extremes varies from country to country in the Western Pacific depending on the geographical location of an island country. For example, in Samoa flooding was often associated with excessive rainfall related to strong La Niña events (e.g. severe flooding in 2001 caused damage to about 1300 buildings in Apia). On the other hand, a strong 2011 La Niña event brought severe drought in Tuvalu.

El Niño is often associated with significant rainfall deficits in countries southwest of the SPCZ including Fiji and Samoa which occasionally results in a meteorological drought. On the northern side of SPCZ, droughts are associated with prolonged southwest displacement of the SPCZ, which occurs during La Niña events. If a tropi- 
cal cyclone or a tropical depression occurs in the vicinity of Fiji and Samoa, especially if a system is moving slowly and staying stationary for a few days, then even during El Niño episodes it can temporarily break a drought or even cause flooding.

Droughts have severe impacts on the natural environment and society of Fiji, Samoa, Tuvalu and other Pacific Island Countries. In 1997/1998 (El Niño episode), severe drought affected Samoa, and then another drought in 2002/2003 when electricity shortages occurred due to lack of water for hydro-electricity. During these dry conditions, fire caused significant damage to forests in Samoa. According to the Samoa Fire Service, 800 hectares of Asau and Aopa forests were destroyed by fire in 2011 (also an El Niño episode).

In extreme cases, droughts affect countries to such an extent that they cause devastating water crisis (e.g. the 2011 drought in Tuvalu). In this paper, a case study for the 2011 Tuvalu drought is discussed, along with detailed analysis of seasonal climate prediction for the region as one of the efficient ways for producing early warnings about climate extremes, including expected dry or wet conditions. It is demonstrated that seasonal climate prediction could be a potentially effective solution to adapt to climate variability and change in small island countries with vulnerable economies.

The paper is organised as following. The current climate of Fiji, Samoa and Tuvalu, temperature and rainfall changes over the past decades and association of rainfall with the ENSO phases is presented in Section 2. In Section 3, we describe the impacts of recent severe weather and climate extremes on island countries: A tropical cyclone Evan which devastated Samoa and Fiji in December 2012; severe floods in Fiji in January and March 2012; and the 2011 drought in Tuvalu. The current status of the science of seasonal climate prediction and case studies which demonstrate the high skill of a dynamical climate model for forecasting dryer or wetter than average (climatology) conditions are presented in Section 4. In Section 5, we discuss the obtained results and present concluding remarks.

\section{Current Climate of Fiji, Samoa and Tuvalu and Its Change over the Past Decades}

Fiji, Samoa and Tuvalu are island countries located in the Western South Pacific Ocean with a tropical maritime climate characterized by warm temperatures all year around. Fiji is an island country in Melanesia. The country comprises an archipelago of 332 islands, of which 111 are permanently inhabited, amounting to a total land area of circa 18,333 $\mathrm{km}^{2}$. The two major islands, Viti Levuand Vanua Levu, account for 95\% of the population of 837,271 [7]. Samoa is an island country in Polynesia. The total land area is $2934 \mathrm{~km}^{2}$, consisting of the two large islands of Upoluand Savai'i which account for $99 \%$ of the total land area and eight small islets. Samoa has a population of 194,320 with about three-quarters of the population living on the main island of Upolu (http://en.wikipedia.org/wiki/Samoa). Tuvalu is a Polynesian island nation; the country comprises three reef islands and six atolls. Its population of 11,200 makes it the third-least populous sovereign state in the world, with only Vatican City and Nauru having fewer inhabitants. In terms of physical land size, at just $26 \mathrm{~km}^{2}$ Tuvalu is the fourth smallest country in the world (http://en.wikipedia.org/wiki/Tuvalu).

The countries have two distinct seasons-a warm and wet season (November to April) and a cooler but relatively dry season (May to October). In this section, detailed analysis of climate in Fiji, Samoa and Tuvalu is presented. The analysis has been performed based on long-term historical climate records obtained from their respective NMSs. Meteorological data have been analysed using the Pacific Climate Change Data Portal available through the Australian Bureau of Meteorology web site http://www.bom.gov.au/climate/pccsp/. Seasonal and interannual variability of temperature and rainfall have been examined and long-term trends have been derived. Significant climate variability in the countries has been identified and has been related to the ENSO. Historical tropical cyclone data used in this study have been recently revised [8] and here we analyse them using the Pacific Tropical Cyclone Data Portal available at http://www.bom.gov.au/cyclone/history/tracks/ [9].

\subsection{Climate of Fiji}

The annual average temperature across Fiji varies from around $27^{\circ} \mathrm{C}$ in coastal regions to about $20^{\circ} \mathrm{C}$ in elevated inland regions. Seasonal changes in the temperature are relatively small and strongly related to changes in the surrounding ocean temperature. Around the coast, the average night-time temperatures can be as low as $18^{\circ} \mathrm{C}$ and the average maximum day-time temperatures can be as high as $32^{\circ} \mathrm{C}$. At elevated altitudes of the central parts on the main islands, average night-time temperatures can be as low as $15^{\circ} \mathrm{C}$.

Rainfall across Fiji is highly variable. On Fiji's two main islands, Viti Levu and Vanua Levu, rainfall is 
strongly influenced by high mountain peaks up to $1300 \mathrm{~m}$. On the south-eastern slopes of Viti Levu, near Suva, the average annual rainfall is about $3000 \mathrm{~mm}$. In contrast, the lowlands on the western side of Viti Levu, near Nadi, are sheltered by the mountains and have an annual average rainfall of about $1800 \mathrm{~mm}$ with a well-defined dry season. Fiji's climate is also influenced by the trade winds blowing from the east or south-east directions associated with the Hadley Circulation. The trade winds bring moisture onshore causing heavy showers in the interior and eastern parts of larger islands.

Analysis of historical climate records at two Fijian meteorological stations with long term high quality records, Nadi Airport and Laucala Bay (Suva), demonstrated that annual maximum and minimum temperatures have increased in both Suva and Nadi since the 1950s (Figure 1 and Figure 2). In Suva, rates of increase were about $0.16^{\circ} \mathrm{C}$ and $0.11^{\circ} \mathrm{C}$ per decade for maximum and minimum temperatures, respectively and in Nadi-about $0.18^{\circ} \mathrm{C}$ and $0.12^{\circ} \mathrm{C}$ per decade for maximum and minimum temperatures, respectively.

Rainfall data for Suva and Nadi Airport since the 1950s shows no clear trends in annual rainfall; but decadal variability is evident, especially at Suva (Figure 3). There is also substantial interannual rainfall variability related to the ENSO phases. In Fiji, El Niño events typically bring drier than average (i.e. climatology) conditions, while La Niña events usually bring wetter than normal conditions (Figure 4).

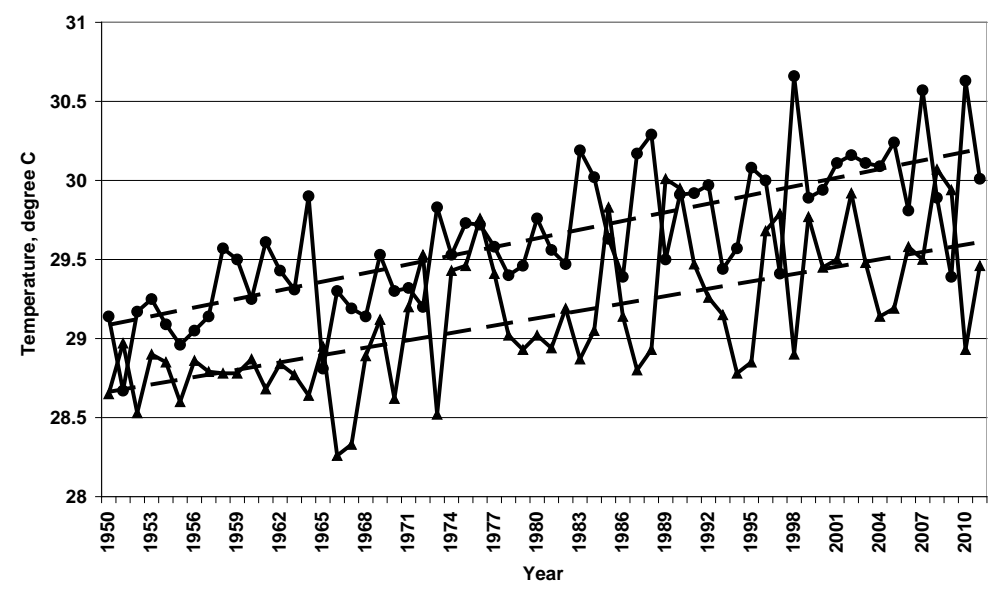

Figure 1. Time series of annual maximum temperatures for Nadi (dots) and Suva (triangles), Fiji, with trend lines superimposed (dashed). Data retrieved through the Pacific Climate Change Data Protal at http://www.bom.gov.au/climate/pccsp/.

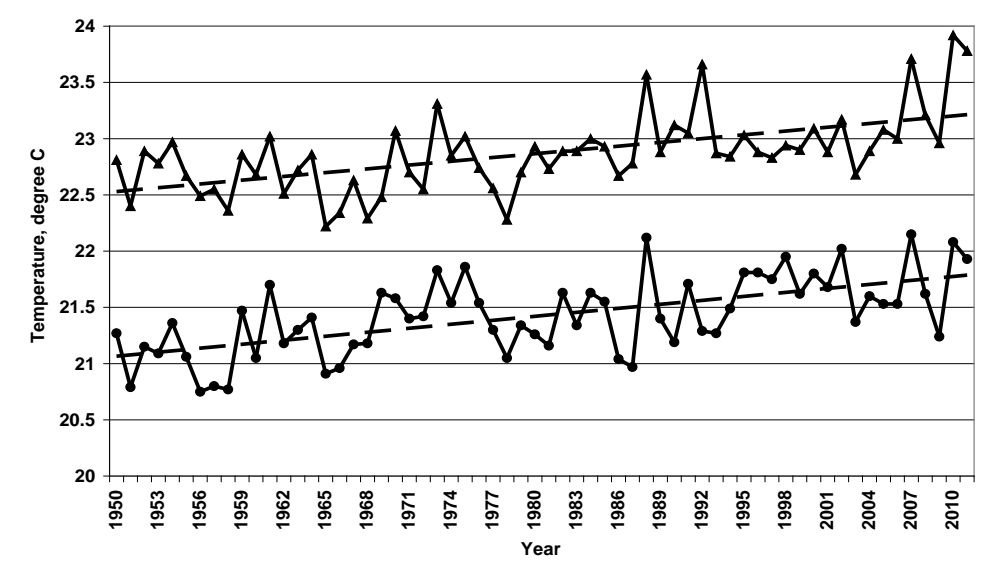

Figure 2. Time series of annual minimum temperatures for Nadi (dots) and Suva (triangles), Fiji, with trend lines superimposed (dashed). Data retrieved through the Pacific Climate Change Data Protal at http://www.bom.gov.au/climate/pccsp/. 

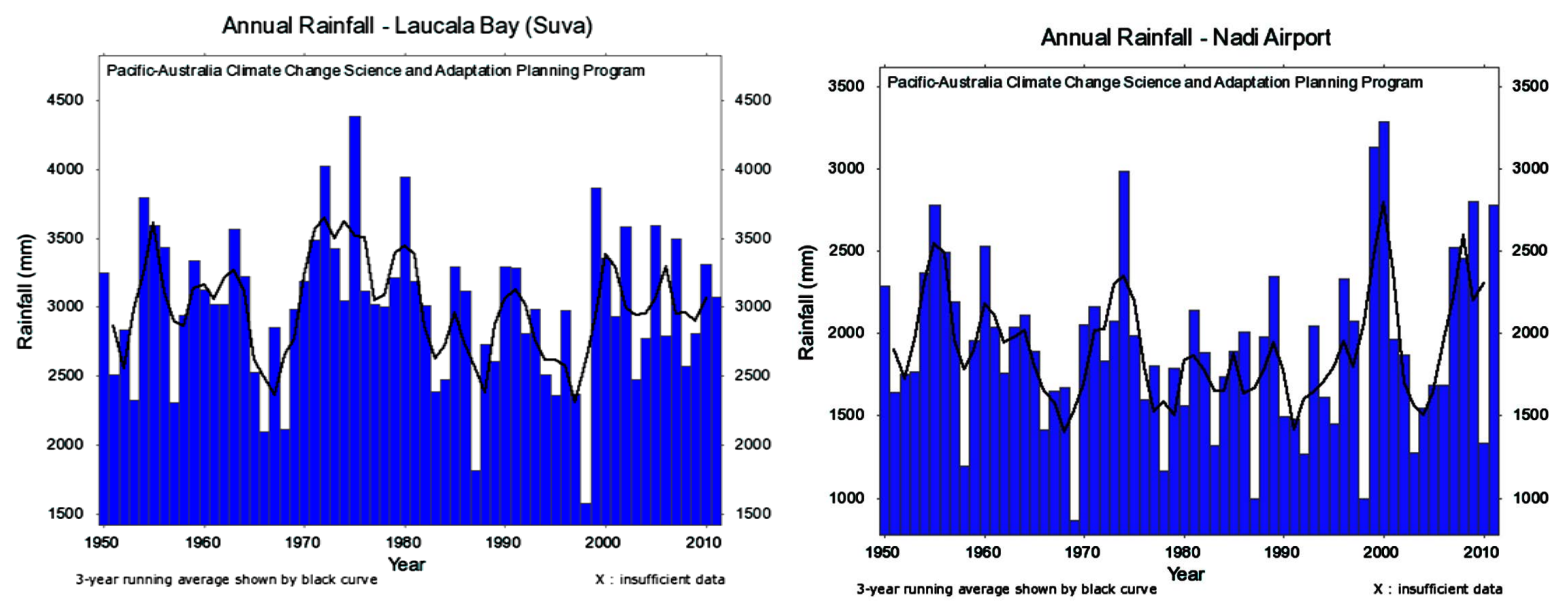

Figure 3. Time series of annual rainfall for Suva (left) and Nadi (right), Fiji. Data retrieved through the Pacific Climate Change Data Protal at http://www.bom.gov.au/climate/pccsp/.
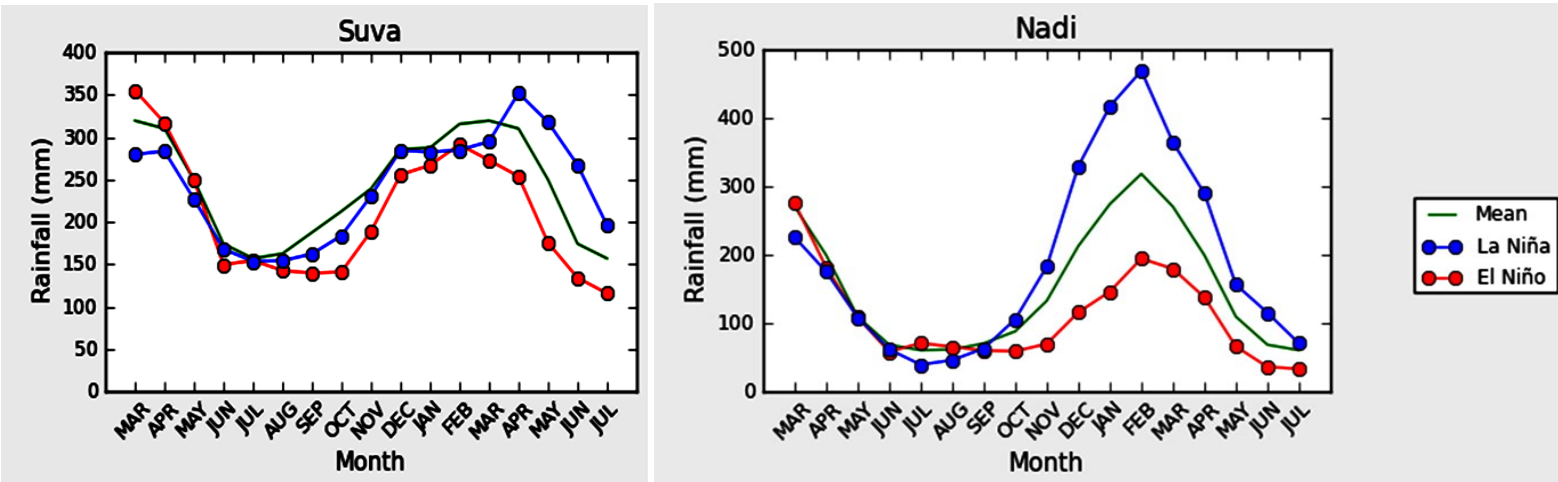

Figure 4. Time series of average monthly rainfall in Suva (left) and Nadi (right), Fiji, for El Niño (blue) and La Niña (red) years, with climatology (green). Data retrieved through the WMO Global Producing Centre (GPC) for long-range forecast portal at http://poama.bom.gov.au/experimantal/pasap/index.shtml.

\subsection{Climate of Samoa}

Temperatures in Samoa are generally consistent throughout the year, with the annual average temperature around $26^{\circ} \mathrm{C}-27^{\circ} \mathrm{C}$. Seasonal differences are very small, with temperatures being coolest in July, when the cool, dry south-east trade winds are strongest. The warmest month is March. The country has distinct wet and dry seasons. On average 75\% of Samoa's total annual rainfall occurs in the wet season. Samoa's mountains have a significant effect on rainfall distribution. Wetter areas are located in the south-east and relatively sheltered, drier areas-in the north-west.

In Apia, which is located in coastal area of the Upolu Island, annual maximum and minimum temperatures have increased at a rate of about $0.08^{\circ} \mathrm{C}$ and $0.05^{\circ} \mathrm{C}$ per decade respectively since the 1960 s (Figure 5 and Figure 6).

Apia's rainfall shows no clear trends in annual rainfall since the 1960s (Figure 7, left panel). The substantial interannual variability in rainfall observed in Apia is related to the ENSO phases. In Samoa, El Niño events tend to bring conditions that are drier than average (climatology), while La Niña events usually bring wetter than average conditions (Figure 8, left panel).

\subsection{Climate of Tuvalu}

In Funafuti, the capital of Tuvalu, there is little variation in temperature throughout the year. The maximum temperature is between $31^{\circ} \mathrm{C}-32^{\circ} \mathrm{C}$ and the minimum temperature is between $25^{\circ} \mathrm{C}-26^{\circ} \mathrm{C}$ all year round. Air 


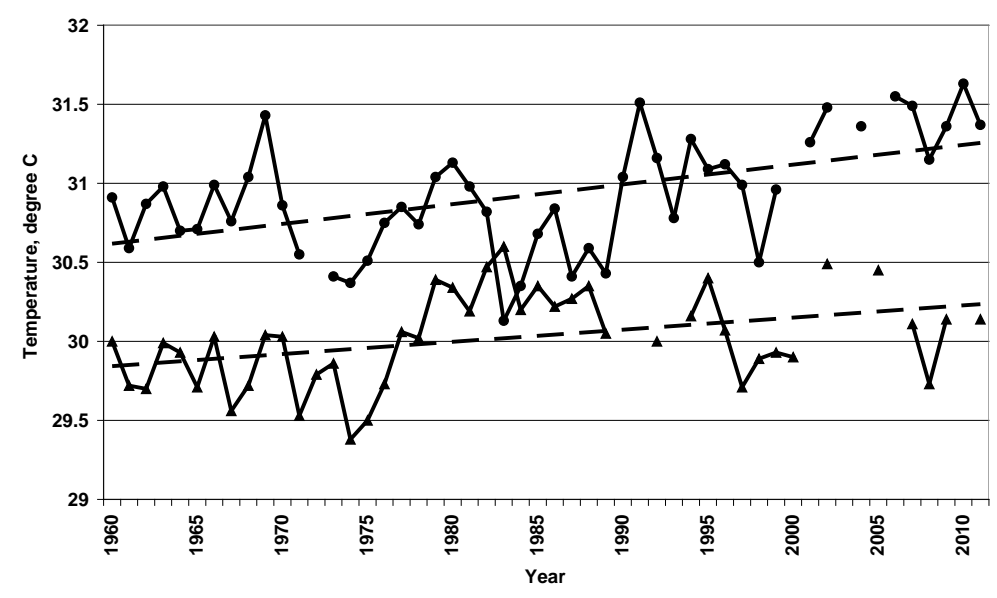

Figure 5. Time series of annual maximum temperatures for Apia, Samoa (triangles), and Funafuti, Tuvalu (dots), with trend lines superimposed (dashed). Data retrieved through the Pacific Climate Change Data Protal at http://www.bom.gov.au/climate/pccsp/.

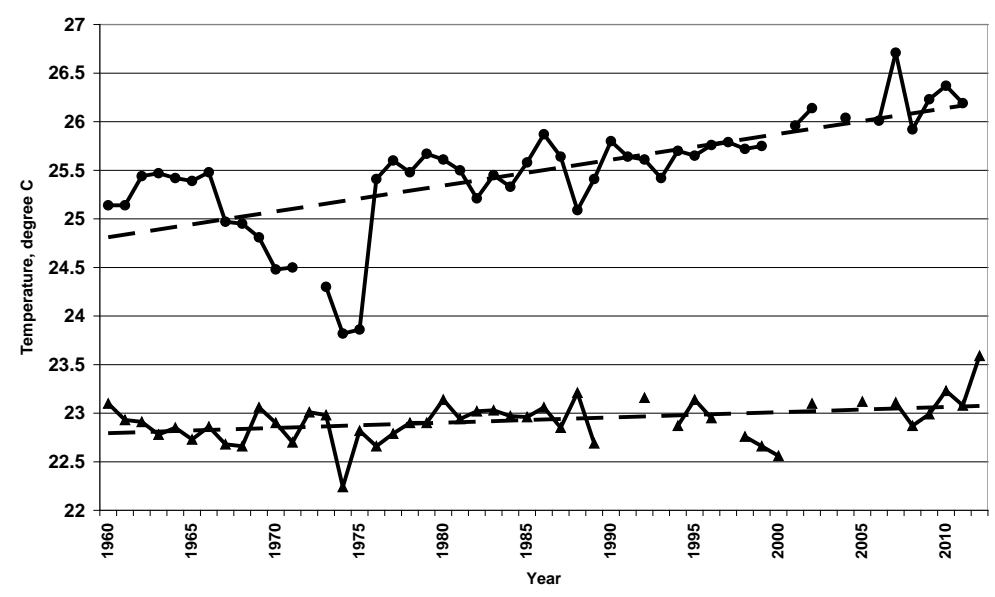

Figure 6. Time series of annual minimum temperatures for Apia, Samoa (triangles), and Funafuti, Tuvalu (dots), with trend lines superimposed (dashed). Data retrieved through the Pacific Climate Change Data Protal at http://www.bom.gov.au/climate/pccsp/.

temperatures are strongly related to the ocean temperatures surrounding the islands and atolls of the country. While Tuvalu also has two distinct seasons, wet and dry, seasonal rainfall variability in Funafuti is not as strongly pronounced as in some other Pacific Island Countries, with rainfall averages being in a range between 200 and $400 \mathrm{~mm}$ each month of the year (Figure 8, right panel). This is attributed to the location of Tuvalu near the West Pacific Warm Pool, where thunderstorm activity occurs all year round. Tuvalu's wet season is affected by the movement and strength of the SPCZ. The WPM can also bring heavy rainfall to Tuvalu during the wet season. Tuvalu's rainfall varies considerably from year to year due to ENSO and SPCZ displacement. In Funafuti, El Niño events tend to bring wetter conditions than average (climatology), while La Niña events usually bring drier than average conditions (Figure 8, right panel).

Annual average maximum and minimum temperatures have increased in Funafuti since the 1960s at rates of about $0.13^{\circ} \mathrm{C}$ and $0.27^{\circ} \mathrm{C}$ per decade, respectively (Figure 5 and Figure 6). The notable negative temperature anomalies in the minimum and maximum temperature records between the mid-1960s and mid-1970s at Funafuti (and similar but less pronounced anomalies in Apia) suggest there could be unresolved homogeneity issues in the temperature records. Rainfall data for Funafuti since the 1960s shows substantial variation in rainfall from 

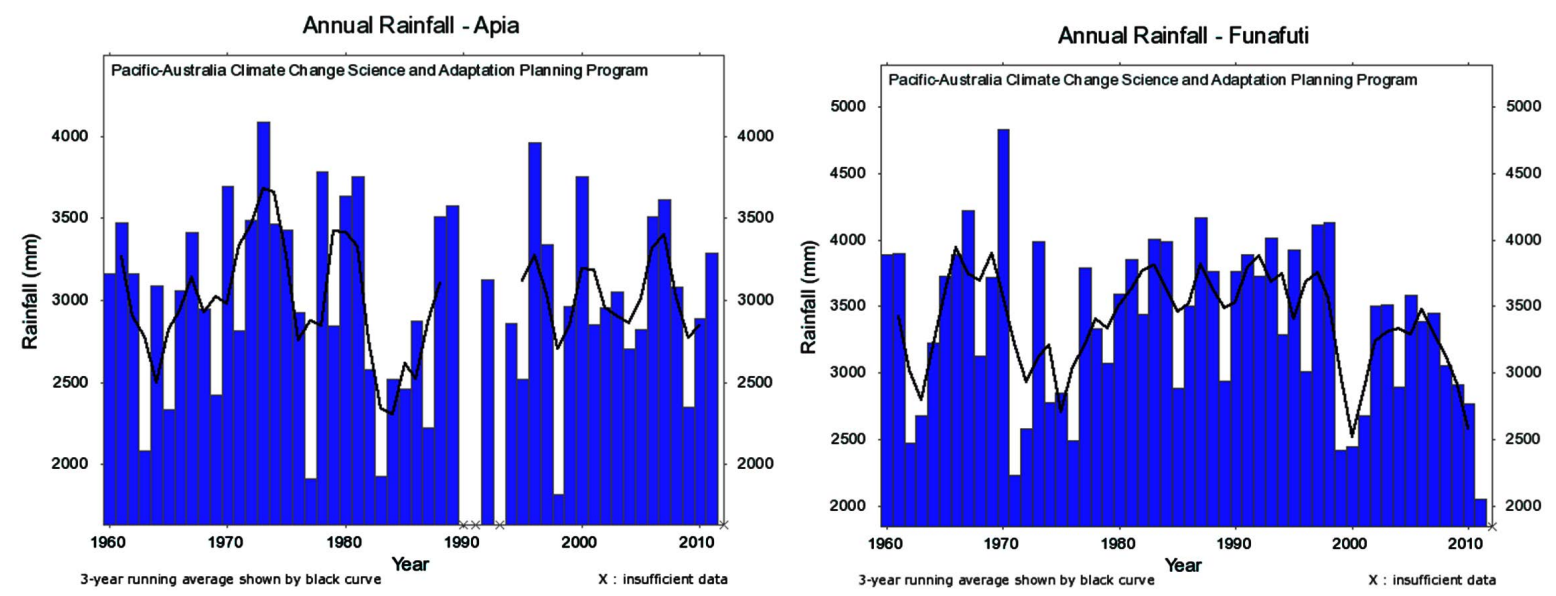

Figure 7. Time series of annual rainfall for Apia, Samoa (left panel) and Funafuti, Tuvalu (right panel). Data retrieved through the Pacific Climate Change Data Protal at http://www.bom.gov.au/climate/pccsp/.
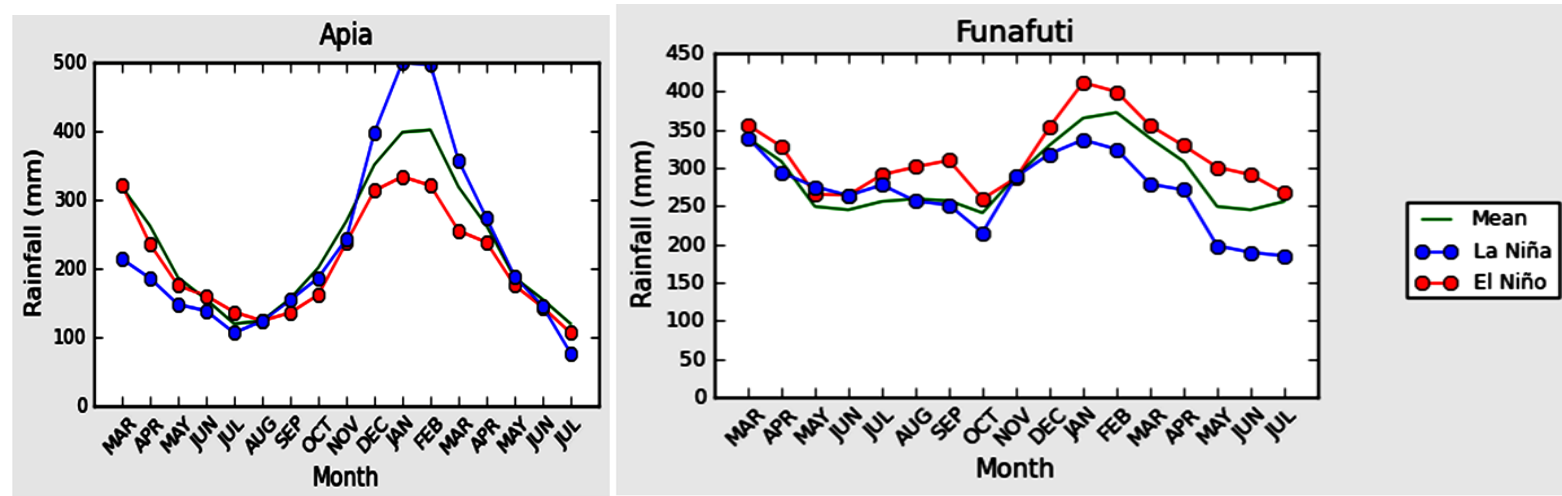

Figure 8. Time series of average monthly rainfall in Apia, Samoa (left panel) and Funafuti, Tuvalu (right panel), for El Niño (blue) and La Niña (red) years, with climatology (green). Data retrieved through the WMO Global Producing Centre (GPC) for long-range forecast portal at http://poama.bom.gov.au/experimantal/pasap/index.shtml.

year to year (Figure 7, right panel).

\subsection{Climate of Island Countries-A Brief Summary}

Recent research undertaken under the Pacific Climate Change Science Program found that in general climate of the Pacific region is undergoing gradual transition which is driven by both natural and anthropogenic forces. These changes are clearly manifested in steady air and ocean temperatures warming, sea level rise and shift in rainfall patterns [6]. The updated homogeneous records indicate that there is spatially consistent warming across the Western Pacific island over 1961-2011, with rates ranging from $+0.05^{\circ} \mathrm{C}$ to $+0.34^{\circ} \mathrm{C}$ per decade, across the network as a whole. A simple regional mean of Pacific island series shows a trend of $+0.18^{\circ} \mathrm{C}$ per decade. This warming trend is consistent with the global rate of warming since 1951 (1951-2012, $0.12^{\circ} \mathrm{C}$ per decade; [2]). Overall, the warming in Pacific Island temperature records over the past half-century is consistent with that expected from human-induced global warming and is large relative to natural interannual variability associated with factors such as the ENSO [10] [11].

Changes in historical climate extremes in the Western Pacific have been also analysed under the Pacific Australian Climate Change Science and Adaptation Planning Program (PACCSAP; [12]). Meteorological observation data obtained from the NMSs have been analysed using a suite of indices in order to define a range of climate extremes, which have been developed by the WMO Expert Team on Climate Change Detection and Indices (ETCCDI). Large shifts in extreme events, including a dramatic increase in warm nights and hot days and a decline in cool extremes have been found, with a less coherent trend in rainfall extremes [10] [13] [14]. 


\section{Weather and Climate Extremes in the Western Pacific: Impacts of Tropical Cyclones, Floods and Droughts on Island Countries}

Weather and climate extremes produce significant impacts on Pacific Island Countries. Torrential rain associated with tropical cyclones and rainfall variability associated with the ENSO and the position of the SPCZ can result in heavy rainfall and subsequent flooding. On the other hand, prolonged rainfall deficit often results in droughts in the region. Such weather and climate extremes can cause economic and social hardship affecting agricultural productivity, infrastructure and economic development which can persist for many years after the initial impact. In this section, we describe extreme events (a tropical cyclone, floods and droughts) which have recently affected Fiji, Samoa and Tuvalu and have caused major economic and social disruption in these countries.

\subsection{Tropical Cyclone Evan}

Recently, severe tropical cyclone Evan affected both Samoa and Fiji in December 2012. Severe tropical cyclone Evan was considered to be the worst tropical cyclone to affect Samoa since cyclones Ofa and Val devastated the country in 1990 and 1991, respectively. Cyclone Ofa produced gales or high winds, resulting in widespread damage due to a combination of storm surge and high seas (Figure 9). In Samoa, seven people were killed and damage totalled to US \$130 million. Extreme damage to crops and tress were also recorded. Just one year later, severe tropical cyclone Val devastated the country again. Overall damages caused by cyclone Val in Samoa have been estimated as US \$200 million due to damage to electrical, water, and telephone connections and destruction of various government buildings, schools, and houses. It took a long time for the country to recover after such devastation, but two decades later, in December 2012, even bigger destruction occurred due to impacts of severe cyclone Evan.

The system was first noted on the 9 December, as a weak tropical depression about $700 \mathrm{~km}$ to the northeast of Suva, Fiji. Over the next couple of days the depression gradually developed further before it was named, by Regional Specialised Meteorological Centre (RSMC) Nadi, Evan on the 12 December, as it had developed into a tropical cyclone. During that day the system moved towards Samoa (Figure 10) and gradually intensified, before the system slowed down and severely affected the Upolu and Savaii Islands during the next day. Then the cyclone made an anticlockwise turn and continued moving towards Fiji. On the 17 December, cyclone Evan had reached its peak intensity with 10-minute wind speeds of $185 \mathrm{~km} / \mathrm{h}$ continuing moving around the coast of the Fijian island of Viti Levu (Figure 11), devastating the island and then gradually weakening while it was moving over the island's west coast. On the 19 December, RSMC Nadi reported that cyclone Evan had weakened below cyclone intensity and declassified it as a tropical cyclone.

Significant progress in operational tropical cyclone forecasting has been achieved over the recent years which has resulted in improved early warning systems, but the death toll attributed to cyclones is still high. In Samoa, at least 14 deaths have been confirmed and 10 sailors were missing as a result of the impact of cyclone Evan. In Fiji, more than 400 people were evacuated by authorities from isolated resorts on small islands and from low-lying areas to emergency shelters in preparation for cyclone’s impact. Such timely measures yielded excel-
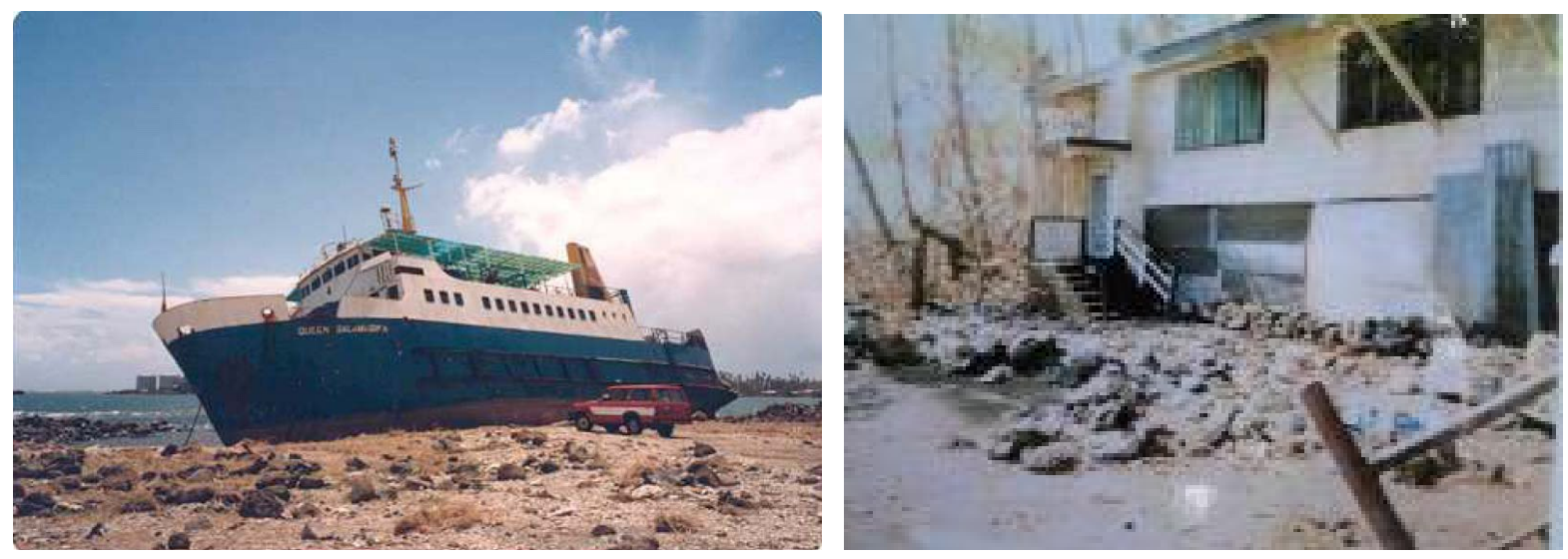

Figure 9. Damage in Apia caused by category 4 tropical cyclone Ofa: The beaching of the passenger/cargo ferry Queen Salamasina in Apia (left) and damage to houses (right). 


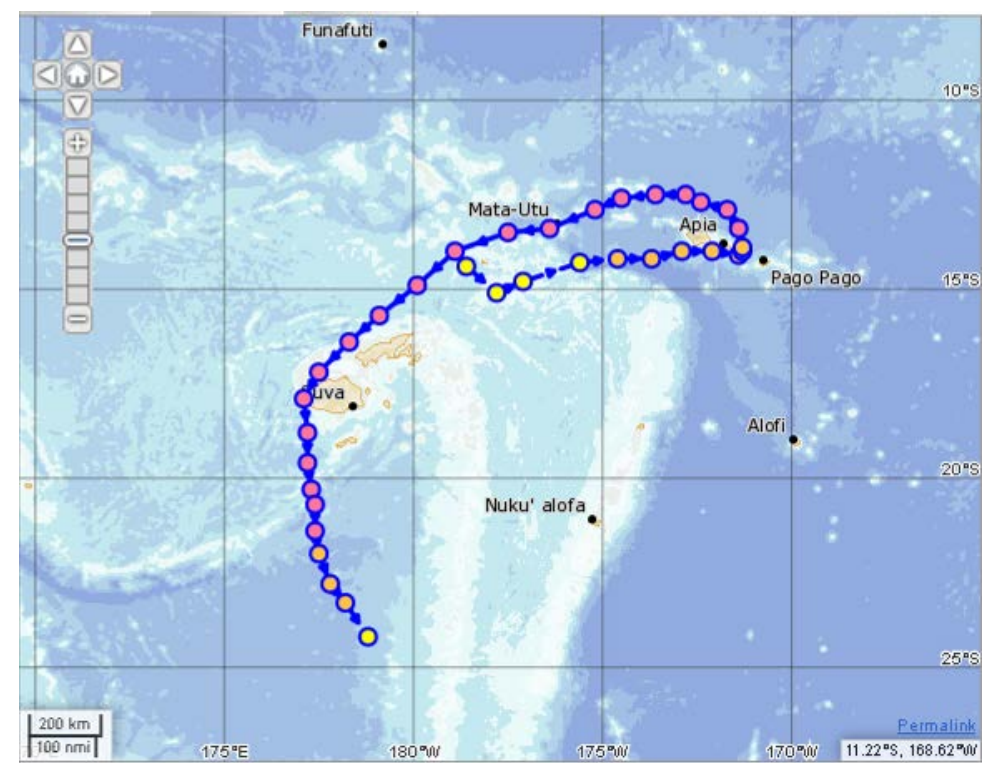

Figure 10. Track of tropical cyclone Evan.

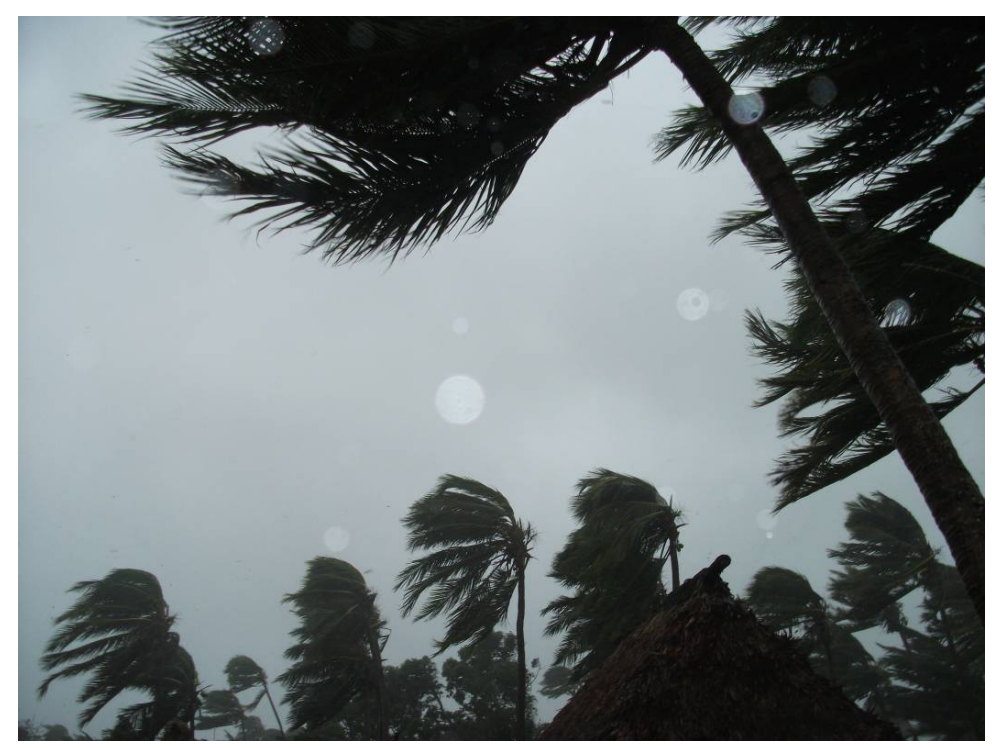

Figure 11. Cyclone Evan produced heavy rainfall and high winds.

lent results-no death reports in Fiji related to cyclone Evan. However, with the cyclone passing in close vicinity of the Fijian islands, damage to vegetation and man-made structures was significant (see examples in Figure 12 and Figure 13) and over 8000 people were living in temporary shelters upon the cyclone passing over the Fiji region.

Significant progress in operational tropical cyclone forecasting has been achieved over the recent years which have resulted in improved early warning systems, but the death toll attributed to cyclones is still high. In Samoa, at least 14 deaths have been confirmed and 10 sailors were missing as a result of the impact of cyclone Evan. In Fiji, more than 400 people were evacuated by authorities from isolated resorts on small islands and from lowlying areas to emergency shelters in preparation for cyclone's impact. Such timely measures yielded excellent results — no death reports in Fiji related to cyclone Evan. However, with the cyclone passing in close vicinity of the Fijian islands, damage to vegetation and man-made structures was significant (see examples in Figure 12 and Figure 13) and over 8000 people were living in temporary shelters upon the cyclone passing over the Fiji region. 


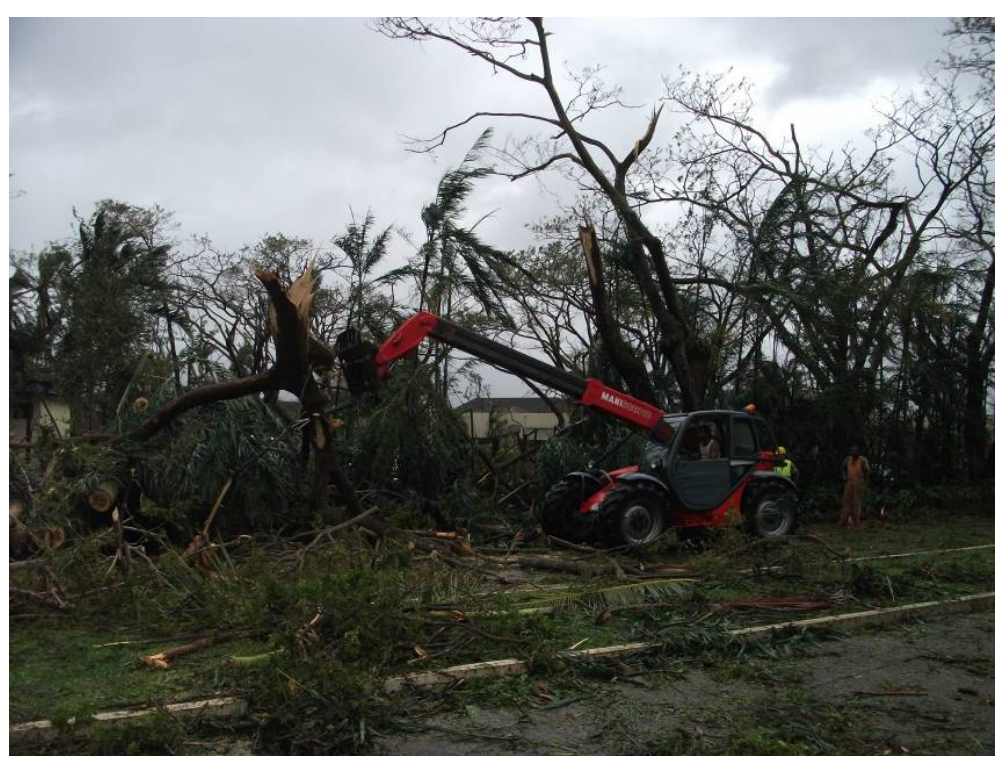

Figure 12. Clearing damage to vegetation in Fiji after cyclone Evan.

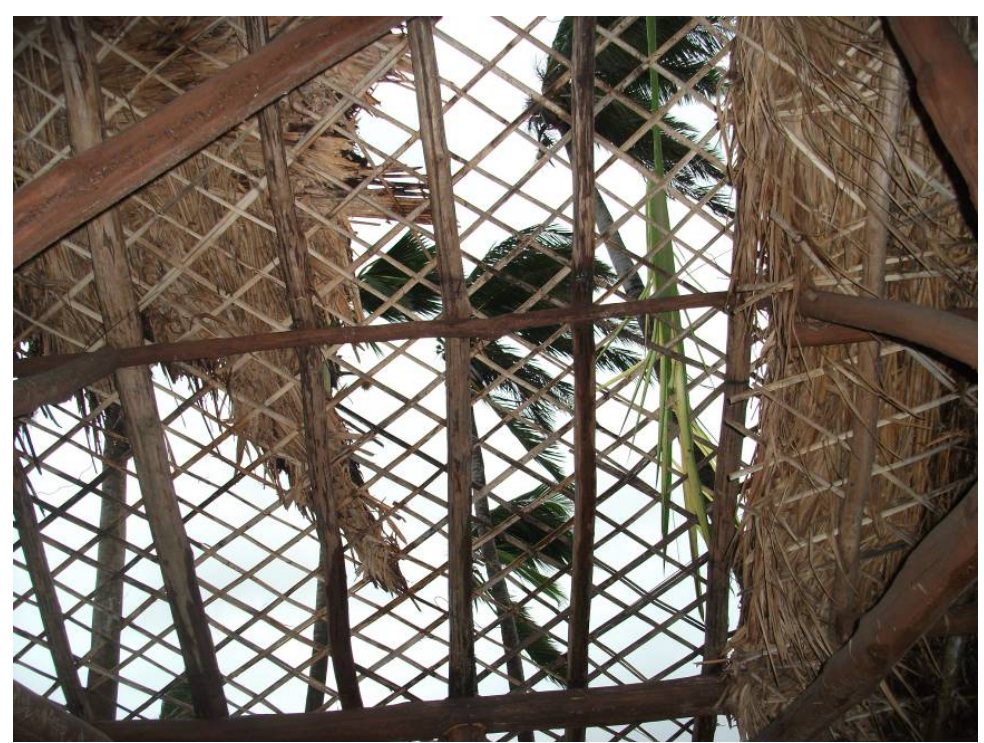

Figure 13. Damage to a roof of a traditional house in Nadi, Fiji Nadi, caused by cyclone Evan.

Cyclone-related economic losses also remain very high, causing significant negative impacts on the economies of both countries. Assessment of the cost of damage caused by cyclone Evan to Fiji indicates total losses of about FJ \$194.9 million (US \$108 million) or about 2.6\% of country's gross domestic product (GDP) [15]. Additionally, losses of FJ \$73.4 million (US \$40.9 million) to the economic flows are expected in the short to medium term. In Samoa, economic losses due to the cyclone's impact were even higher. The value of durable physical assets across all economic and social sectors destroyed by Evan (referred to as damage) is estimated at SAT 235.7 million, equivalent to US \$103.3 million. In addition, production losses and higher production costs arising from the disaster across all sectors (referred to as losses) are estimated at SAT 229.4 million, or US $\$ 100.6$ million. Thus the total costs of the disaster amount to SAT 465 million or US \$203.9 million.

\subsection{The 2012 Fiji Floods}

Severe floods frequently affect major infrastructure, transportation, business and property in Pacific Island 
Countries. Often significant flooding is attributed to a tropical cyclone or a tropical depression. In this section, we present information on the significant floods in January and March 2012 which affected Fiji and were caused by tropical depressions.

On the 19 January the Fiji Meteorological Service’s RSMC Nadi reported that a tropical disturbance had developed along an active trough of low pressure to the north of Fiji. Over the next couple of days, the tropical disturbance moved towards the south before it developed into a tropical depression and moved across Vanua Levu during the 21 January. Once over Vanua Levu, the depression remained stationary causing widespread heavy rainfall and strong winds over Fiji's Northern and Eastern divisions until the 25 January, when it weakened and started to move away to the southeast.

Above average rainfall in the preceding three months across most the country and heavy rains from the middle of January lead to unprecedented flooding and landslides, which led to a state of emergency being declared late in the month. The flooding was worst in the western part of the main island of Viti Levu. Eight people were reported to have died in the floods, most of them on the main island, and thousands of people were displaced, with about 3500 people placed in temporary shelters. Power and water supply disruptions were experienced in many areas, and roads were washed away. Further damage was caused to crops and to other infrastructure. Estimated losses due to the January 2012 flood were about FJ \$40 million [16].

Just two months later, another severe flood devastated the country. The March 2012 flood was the worst flood to affect Fiji in recent times in terms of both the magnitude and the damage to properties (Figure 14). On the 28 March, a tropical depression which was moving slowly over Fiji for almost a week, became stationary just west of Viti Levu. Overnight on the 29 March, the tropical depression underwent rapid development and it triggered the torrential, widespread and high-intensity rain over Fiji. Rain was particularly torrential and prolonged in the Western Division, which consequently led to severe flooding of major rivers, streams and low-lying areas in the Division until the 1 April. As for the January floods, antecedent conditions played a more role, with wetter than normal conditions experienced from the beginning of the year. At Nadi Airport, February rainfall was near double the monthly mean and a further $130 \mathrm{~mm}$ was recorded between 1 and 28 March.

This resulted in massive devastation across the western portion of Viti Levu. The towns of Ba and Nadi which have major rivers running through them were the worst affected during this natural disaster, with the flood height apparently setting a new record. The maximum flood water level recorded by Nadi River gauge before it malfunctioned was $7.6 \mathrm{~m}$. The actual flood level is likely to be just over $8.0 \mathrm{~m}$.

All towns in the Western Division suffered huge losses to business and residential properties. Torrential rain and subsequent flooding resulted in landslides and destruction of major roads and bridges (e.g. the Queens Road from Nadi to Lautoka was damaged by strong currents at several sections, and some bridges were damaged). The total damage caused by the March 2012 flood was estimated at around FJ \$70 million [16].

A brief examination of the rainfall record reveals the Nadi Airport 2012 maximum 1-day rainfall of $291.9 \mathrm{~mm}$ (24 January) to be the fourth highest on record. This amounts to a 1-in-25 year rainfall event for data record that

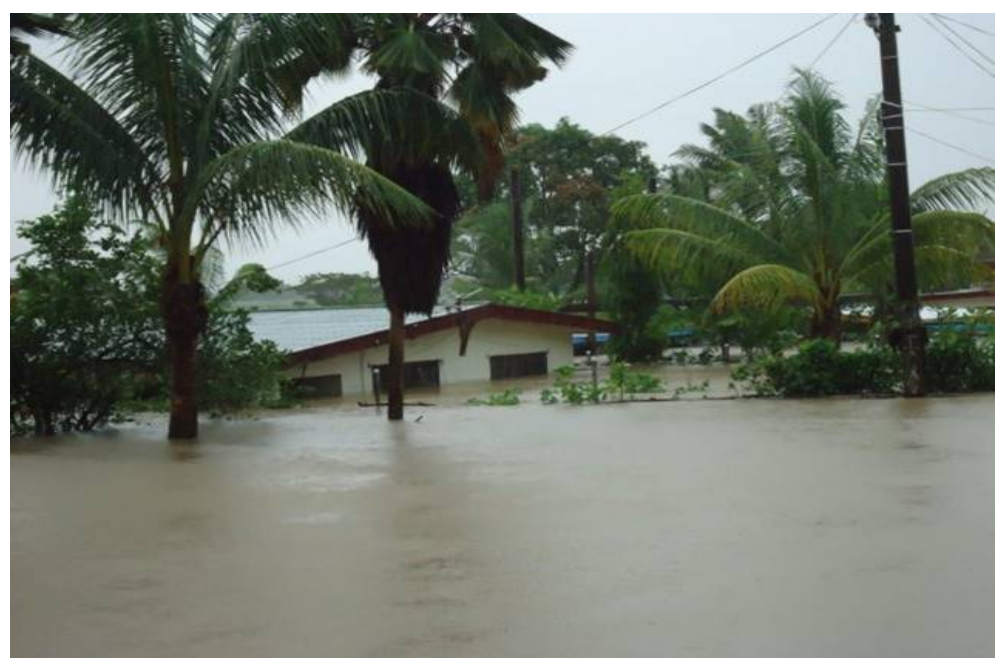

Figure 14. Severe floods in Nadi, Fiji affect and transportation. 
begins in 1942. Of greater interest is the maximum 5-day rainfall of $677.0 \mathrm{~mm}$ recorded between 28 March to 1 April, the second highest 5-day event since 1942, amounting to a 1-in-70 year event. Both the highest 5-day record event in January 2009 and the March 2012 event are associated with prolonged SPCZ activity over Fiji and slow moving tropical depressions over the island nation. These events highlight the high chances of extreme flooding when high intensity rainfall events coincide with saturated ground conditions, especially in short, steep river catchments.

\subsection{The 2011 Tuvalu Drought}

On the other side of hydrological extremes are droughts which also frequently affect islands of the Pacific (Figure 15) impacting on the countries to a various degrees of severity depending on the drought's length. For example, the 2011 Tuvalu drought severely impacted a small island nation living on coral atolls in the Pacific. Water resources in Tuvalu are heavily dependent on an abundant rainfall. If the country experiences a prolonged rainfall deficit, it results in critical shortage of water.

This prolonged drought episode was related to a strong La Niña event which affected the region in 2010-11. Typically, during La Niña years, oceanic waters are cooler than climatology (average conditions) in the region of the Western Central Pacific where Tuvalu is located. As a result of oceanic cooling, atmospheric convection is suppressed and hence the rainfall amount in Tuvalu during La Niña episodes is below average (see Figure 8, right panel).

In 2011, a number of countries and territories in the region, including Samoa, Tokelau and Tonga were affected by La Niña-induced rainfall deficit; however, Tuvalu was particularly seriously impacted. On the 28 September 2011, the government of Tuvalu declared a state of emergency due to critically low water supplies. Households were rationed to about 40 litres (two buckets) of fresh-water a day as some parts of Tuvalu had just a two day supply of water left [17]. The situation was critical and to relieve stress on the population of Tuvalu, the governments of Australia, Japan, New Zealand and South Korea immediately began delivering fresh water supplies and portable desalination plants.

At Funafuti, rainfall was the lowest on record with only $515 \mathrm{~mm}$ (36\% of the long-term average of $1430 \mathrm{~mm}$ ) received between May to October. Severe drought in Tuvalu in the mid-1970s was also associated with a strong La Niña event [18].

\section{Seasonal Climate Prediction-Effective Way to Adapt to Climate Variability and Change}

Severe weather events and climate extremes often affect island nations in the Western Pacific and in this paper

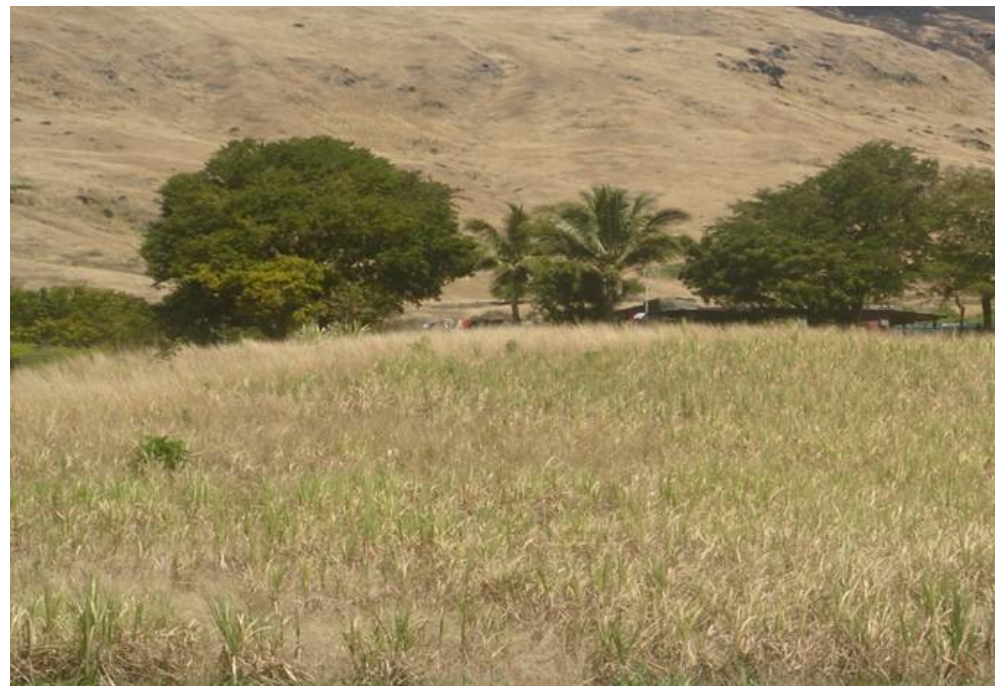

Figure 15. Meteorological drought affected Fiji in 2010. Major infrastructure and transportation. 
we brought a number of recent examples of devastation caused by cyclones, floods and droughts. Damage to the natural environment and economy could be enormous especially taking in consideration that these countries are among the least developed countries. In extreme cases economic loses from such natural disasters could take away a large part of country's annual GDP, as we demonstrated in Section 3.

To implement effective early warning systems with the aim of reducing the impacts of extreme events, climate variability and climate change on the natural environment and society, authorities of island countries develop various action plans as well as adaptation measures. One of the most cost-effective and easy-to-implement ways to adapt to climate variability and change which we discuss here is for authorities to make informed decisions based on the latest achievements of climate science and to efficiently use seasonal climate prediction products which forecast expected rainfall and temperature over the coming season (next three months). Under the Pacific Adaptation Strategy Assistance Program and the Pacific Australia Climate Change Science and Adaptation Planning Program research has been conducted to evaluate the skill of the dynamical climate model POAMA (Predictive Ocean Atmosphere Model for Australia) for predicting seasonal rainfall [19]-[22]. Outputs of POAMA are now delivered through a range of the developed web-based information tools, to help the NMSs in 15 island countries in the Western Pacific with preparing operational monthly seasonal climate outlooks [23].

In this section, we discuss how the timely utilization of seasonal climate prediction information could assist in adaptation to climate change and reduce the hardship which society experiences as the result of increased frequency in climate extremes. To illustrate, we use a case study for the 2011 Tuvalu drought.

The probability of accumulated rainfall falling in the lower climatological tercile (i.e. an elevated risk of below average rainfall) for the Western Central Pacific in 2011 was predicted by POAMA. The high skill of POAMA's rainfall prediction in this region is based on the model's ability to accurately forecast phases of the ENSO. The rainfall deficit in 2011 was related to one of the strongest La Niña episodes in recent history, which lasted for about two years (2010-2012). Observations from meteorological stations from December 2010 to January 2011 already demonstrated that accumulated rainfall in the Western Central Pacific region where Tuvalu is located was more than $500 \mathrm{~mm}$ below the climatological average. Here we verify that POAMA could produce reliable seasonal forecasting, to better understand the tendency for expected rainfall in the region.

The POAMA-based seasonal forecast issued in February 2011 for the three-month period February-MarchApril predicted that the rainfall deficit in the area of Tuvalu would continue, with the ensemble mean forecast quantity of seasonal rainfall about $225 \mathrm{~mm}$ below average (Figure 16, left panel). Subsequent forecasts from POAMA, produced monthly, consistently indicated that rainfall deficits would further continue, e.g. the forecast for August-September-October, issued in August 2011, predicted a rainfall deficit greater than $225 \mathrm{~mm}$ (Figure 16, right panel) with high probability (over $87.5 \%$, Figure 17, left panel). Thus, information available from POAMA from the beginning of 2011 consistently indicated high probability of continuous drought in the region. Such information could trigger a set of early preventive actions to reduce the impact of water shortages on the local population.
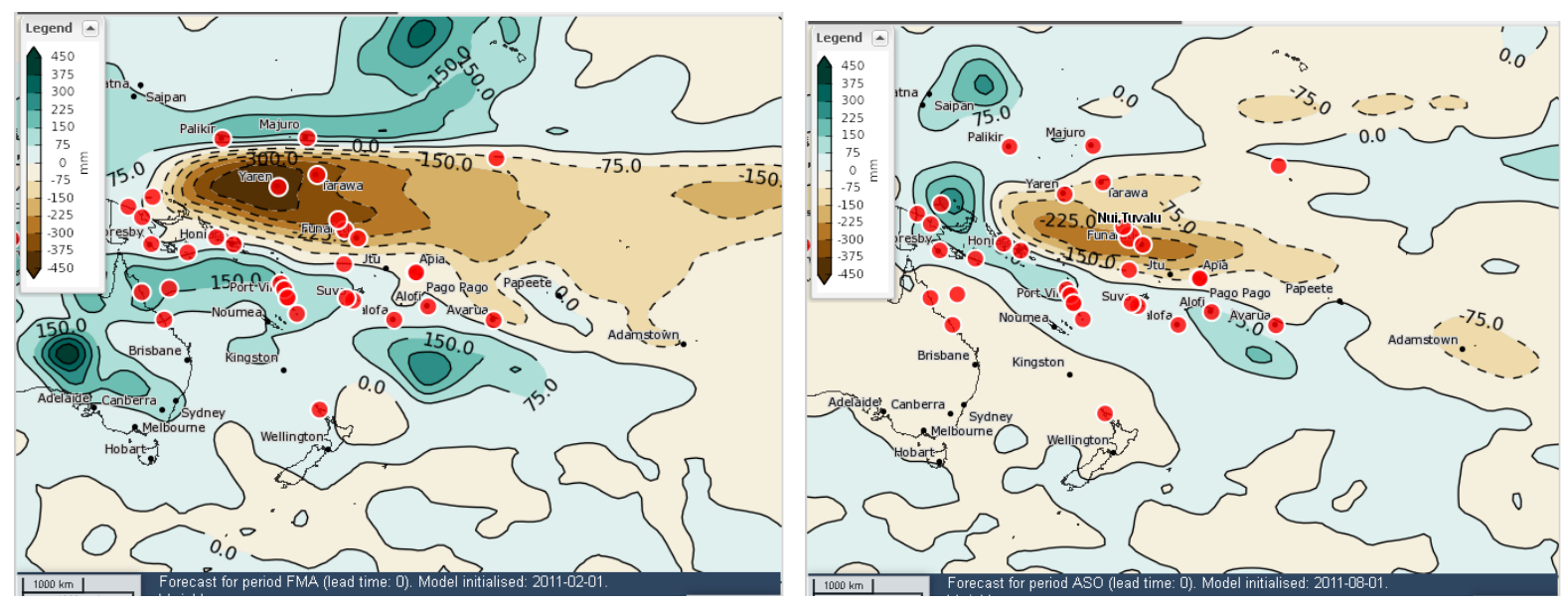

Figure 16. POAMA-based prediction of seasonal rainfall anomalies in the South Pacific region. The seasonal forecasts issued in February 2011 for three-month period (Feb-March-Apr, left panel) and for Aug-Sept-Oct (issued in August 2011, right panel). 


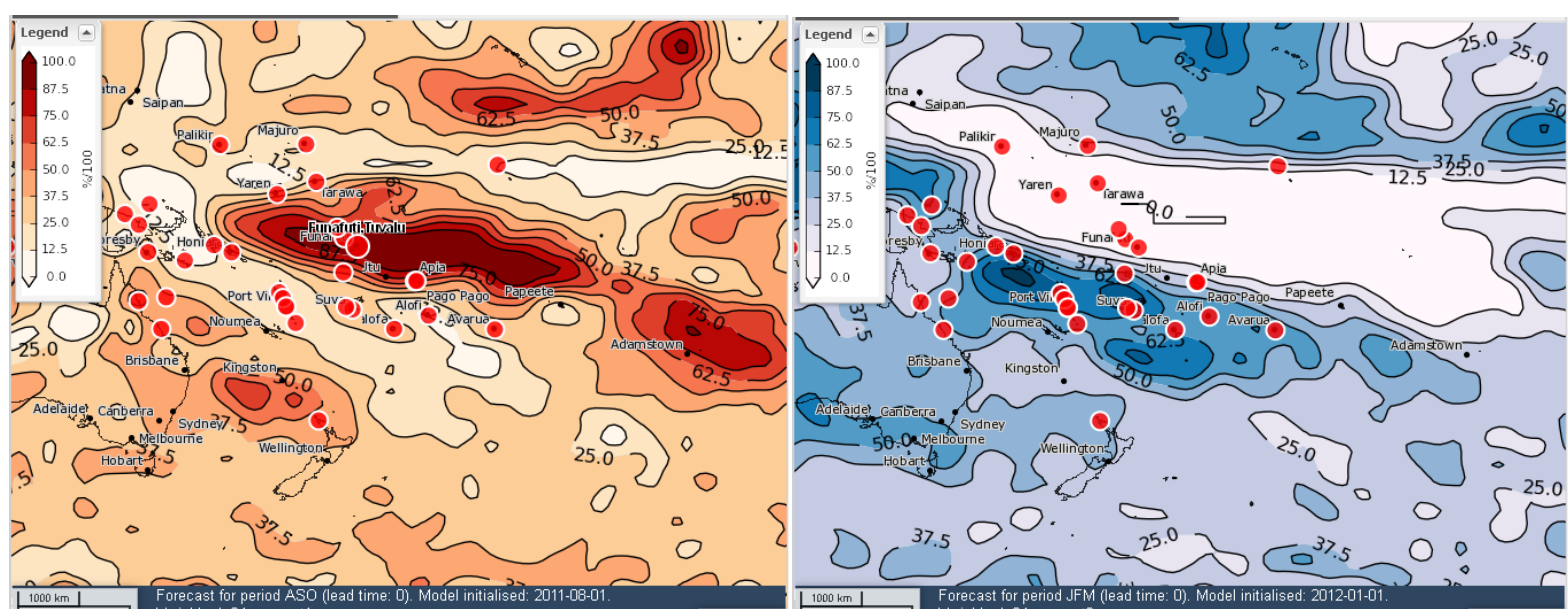

Figure 17. Left panel: Probability of accumulated rainfall in the lower climatological tercile (more than $87.5 \%$ in the region containing Tuvalu) predicited by POAMA for Aug-Sept-Oct 2011. Right panel: Probability of accumulated rainfall in the higher climatological tercile (more than 75\%) predicted by POAMA for Jan-Feb-March 2012.

POAMA demonstrated high skill in predicting seasonal rainfall over the Pacific region and the model's outputs could be used with confidence for forecasting both rainfall deficit leading to droughts and excessive rainfall potentially leading to floods. In Figure 17 (right panel), high probability (above 75\%) of wetter than normal seasonal conditions is predicted by POAMA in the area of Fiji for January-February-March 2012. Exacerbated by additional rainfall from stationary tropical depressions, the 2012 Fiji floods in January and March were among the most devastating natural disasters for the country in the past few decades. Using information about predicted excessive seasonal rainfall, informed decisions could be made by the authorities and local communities to take preventive measures well in advance of the potential flooding and hence save lives and reduce impacts of the disaster.

\section{Discussion and Conclusions}

Collaborative efforts of the National Meteorological Services of Australia and Pacific Island Countries are undertaken through a number of Pacific programs (the Pacific Climate Change Science Program, the Pacific Adaptation Strategy Assistance Program and the Pacific Australia Climate Change Science and Adaptation Planning Program), and have improved the understanding of current and future climate of the Pacific Island Countries. While some recent studies describe impacts of tropical cyclones, floods and droughts on South China [24] [25], till now there were no regional studies on impact of climate extremes on island countries in the Western Pacific. Based on the outcomes of this research, climate change impacts on the natural environment of Pacific Island Countries are now better understood. This is an important step in developing adaptation strategies to reduce the impacts of climate change on Pacific Island Countries.

The most pronounced impacts on the countries come from severe weather and climate extremes and in this paper we presented examples of such impacts caused by tropical cyclones, floods and droughts. Tropical cyclones pose a major risk to the wellbeing and economies of Pacific Island Countries. The impacts of tropical cyclones on the countries are severe and the costs of damage are astronomical. By the end of this century, projections suggest decreasing numbers of tropical cyclones but a possible shift towards more intense categories [26]. In addition, geographical shifts in the distribution of tropical cyclone occurrences caused by a warming of the atmospheric and oceanic environment are possible. Similarly, increases in the frequency of hydrological extremes such as floods and droughts are also projected by climate models [2].

This should be taken into consideration by the authorities of Pacific Island Countries and aid donors when developing adaptation strategies to reduce the increasing risk of climate extremes. Climate science could significantly assist with this task. As we demonstrated here, the modern science of seasonal climate prediction is well developed and could provide assistance to informed decision making in adaptation to climate variability and change. A range of web-based information tools to deliver seasonal climate predictions based on outputs from state-of-the-art dynamical climate model have been developed, to provide National Meteorological Services in 
the Western Pacific with information about expected climate extremes two-three months in advance.

We conclude with confidence that skilful seasonal climate prediction is an effective solution at the regional level to provide governments and local communities of island nations in the Western Pacific with valuable assistance in informed decision making for adaptation to climate variability and change.

\section{Acknowledgements}

The research discussed in this paper was conducted under the Pacific Climate Change Science Program (PCCSP), the Pacific Adaptation Strategy Assistance Program (PASAP) and the Pacific Australia Climate Change Science and Adaptation Planning Program (PACCSAP) supported by the Australian Agency for International Development (AusAID), in collaboration with the Department of Climate Change and Energy Efficiency (DCCEE).

\section{References}

[1] IPCC (2007) Climate Change 2007: The Physical Science Basis. Contribution of Working Group I to the Fourth Assessment Report of the Intergovernmental Panel on Climate Change. In: Solomon, S., Qin, D., Manning, M., Chen, Z., Marquis, M., Averyt, K.B., Tignor, M. and Miller, H.L., Eds., Cambridge University Press, Cambridge, United Kingdom and New York, USA.

[2] IPCC (2013) Climate Change 2013: The Physical Science Basis. Contribution of Working Group I to the Fifth Assessment Report of the Intergovernmental Panel on Climate Change. In: Stocker, T.F., Qin, D., Plattner, G.-K., Tignor, M., Allen, S.K., Boschung, J., Nauels, A., Xia, Y., Bex, V. and Midgley, P.M., Eds., Cambridge University Press, Cambridge, United Kingdom and New York, USA, 1535 p.

[3] Chan, J.C.L. (2000) Tropical Cyclone Activity over the Western North Pacific Associated with El Niño and La Niña Events. Journal of Climate, 13, 2960-2972. http://dx.doi.org/10.1175/1520-0442(2000)013<2960:TCAOTW>2.0.CO;2

[4] Kuleshov, Y., Qi, L., Fawcett, R. and Jones, D. (2008) On Tropical Cyclone Activity in the Southern Hemisphere: Trends and the ENSO Connection. Geophysical Research Letters, 35, Article ID: L14S08. http://dx.doi.org/10.1029/2007GL032983

[5] Risbey, J.S., Pook, M.J., McIntosh, P.C., Wheeler, M.C. and Hendon, H.H. (2009) On the Remote Drivers of Rainfall Variability in Australia. Monthly Weather Review, 137, 3233-3253. http://dx.doi.org/10.1175/2009MWR2861.1

[6] Australian Bureau of Meteorology and CSIRO (2011) Climate Change in the Pacific: Scientific Assessment and New Research. Volume 1: Regional Review, 257 p. Volume 2: Country Reports, 273 p.

[7] Fiji Bureau of Statistics (2013) 2007 Census of Population and Housing. http://www.statsfiji.gov.fj/index.php/2007-census-of-population

[8] Atalifo, T., Prakash, B., Waqaicelua, A., Kunitsugu, M., Caroff, P., Chane-Ming, F., et al. (2013) Tropical Cyclone Data and Portal for the Western Pacific. Proceedings of the 19th National Conference of the Australian Meteorological and Oceanographic Society (AMOS), Melbourne, 11-13 February 2013, 351.

[9] Kuleshov, Y. (2012) Southern Hemisphere Tropical Cyclone Climatology. In: Wang, S.-Y. and Gillies, R.R., Eds., Modern Climatology, Chapter 1, Intech, Vienna, 1-44.

[10] Whan, K., Alexander, L.V., Imielska, A., McGree, S., Jones, D., Ene, E., Finaulahi, S., Inape, K., Jacklick, L., Kumar, R., Laurent, V., Malala, H., Malsale, P., Pulehetoa-Mitiepo, R., Ngemaes, M., Peltier, A., Porteous, A., Seuseu, S., Skilling, E., Tahani, L., Toorua, U. and Vaiimene, M. (2013) Trends and Variability of Temperature Extremes in the Tropical Western Pacific. International Journal of Climatology, 34, 2585-2603.

[11] Jones, D.A., Collins, D.A., McGree, S., Trewin, B., Skilling, E., Diamond, H., et al. (2013) An Updated Analysis of Homogeneous Temperature Data at Pacific Island Stations. Australian Meteorological and Oceanographic Journal, 63, 285-302.

[12] Kuleshov, Y., Spillman, C., Wang, Y., Charles, A., de Wit, R., Shelton, K., et al. (2012) Seasonal Prediction of Climate Extremes for the Pacific: Tropical Cyclones and Extreme Ocean Temperatures. Journal of Marine Science and Technology, 20, 675-683.

[13] Imielska, A., Whan, K., McGree, S., Jones, D. and Alexander, L. (2013) Trends in Rainfall and Temperature Extremes in the Pacific. Proceedings of the 19th National Conference of the Australian Meteorological and Oceanographic Society (AMOS), Melbourne, 11-13 February 2013, 137.

[14] McGree, S., Whan, K., Jones, D., Alexander, L.V., Imielska, A., Diamond, H., et al. (2013) An Updated Assessment of Trends and Variability in Total and Extreme Rainfall in the Western Pacific. International Journal of Climatology, 34, 2775-2791. http://dx.doi.org/10.1002/joc.3874

[15] Business Insurance (2013) Fiji: Cyclone Evan Damage Estimated at \$108 Million, April 24, 2013. 
http://www.businessinsurance.com/article/20130424/NEWS09/130429928\#

[16] Government of Fiji (2012) Cabinet Memorandum: Consolidated 2012 Flood Damage Assessment and Rehabilitation Requirements (for Discussion), April 2012.

[17] Information Bulletin-Tuvalu Drought (2011) International Federation of Red Cross and Red Crescent Organizations, 14 October 2011.

[18] d'Aubert, A. and Nunn, P.D. (2012) Furious Winds and Parched Islands: Tropical Cyclones (1558-1970) and Droughts (1722-1987) in the Pacific. XLibris, Bloomington, 358 p.

[19] Charles, A., Kuleshov, Y. and Jones, D. (2012) Chapter 23: Managing Climate Risk with Seasonal Forecasts. In: Banaitiene, N., Ed., Risk Management-Current Issues and Challenges, InTech, Vienna, 557-584.

[20] Charles, A., Kuleshov, Y., Jones, D., Hendon, H., Shelton, K., de Wit, R., et al. (2013) Seasonal Prediction of Climate Extremes in the Pacific: New Products and Services from Dynamical Models. Proceedings of the 20th International Congress on Modelling and Simulation (MODSIM 2013), Adelaide, 1-6 December 2013, 2841-2847.

[21] Cottrill, A., Hendon, H., Lim, E.-P., Langford, S., Shelton, K., Charles, A., et al. (2013) Seasonal Forecasting in the Pacific Using the Coupled Model POAMA-2. Weather and Forecasting, 28, 668-680. http://dx.doi.org/10.1175/WAF-D-12-00072.1

[22] Cottrill, A. and Kuleshov, Y. (2014) An Assessment of Rainfall Seasonal Forecasting Skill from the Statistical Model SCOPIC Using Four Predictors. Australian Meteorological and Oceanographic Journal, in Press.

[23] Kuleshov, Y., Jones, D., Hendon, H., Charles, A., Cottrill, A., Lim, E.-P., et al. (2012) Pacific Adaptation Strategy Assistance Program: Strengthening the Capacity for Seasonal Prediction Services in Pacific Countries. Bulletin of the Australian Meteorological and Oceanographic Society, 25, 7-12.

[24] Zhang, Q., Zhang, W., Lu, X. and Chen, Y.D. (2012) Landfalling Tropical Cyclones Activities in the South China: Intensifying or Weakening? International Journal of Climatology, 32, 1815-1824. http://dx.doi.org/10.1002/joc.2396

[25] Zhang, Q., Zhang, W., Chen, Y.D. and Jiang, T. (2011) Flood, Drought and Typhoon Disasters during the Last Half Century in the Guangdong Province, China. Natural Hazards, 57, 267-278. http://dx.doi.org/10.1007/s11069-010-9611-9

[26] Knutson, T.R., McBride, J.L., Chan, J., Emanuel, K., Holland, G., Landsea, C., et al. (2010) Tropical Cyclones and Climate Change. Nature Geoscience, 3, 157-163. http://dx.doi.org/10.1038/ngeo779 
Scientific Research Publishing (SCIRP) is one of the largest Open Access journal publishers. It is currently publishing more than 200 open access, online, peer-reviewed journals covering a wide range of academic disciplines. SCIRP serves the worldwide academic communities and contributes to the progress and application of science with its publication.

Other selected journals from SCIRP are listed as below. Submit your manuscript to us via either submit@scirp.org or Online Submission Portal.
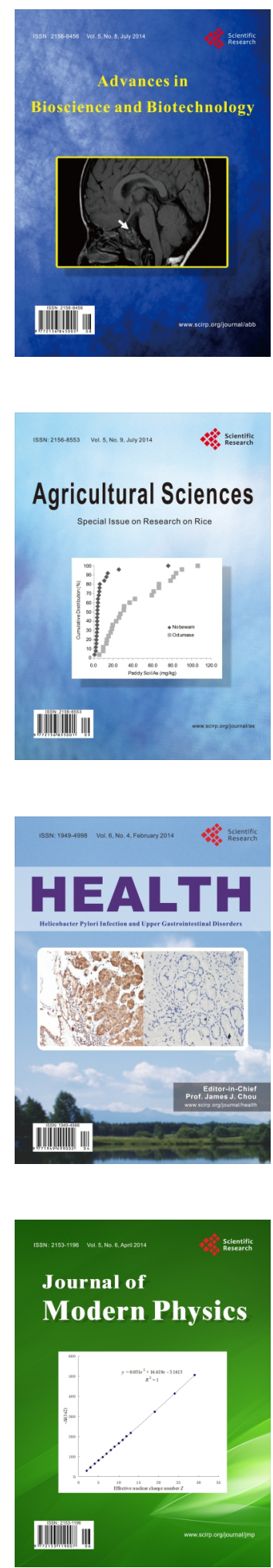
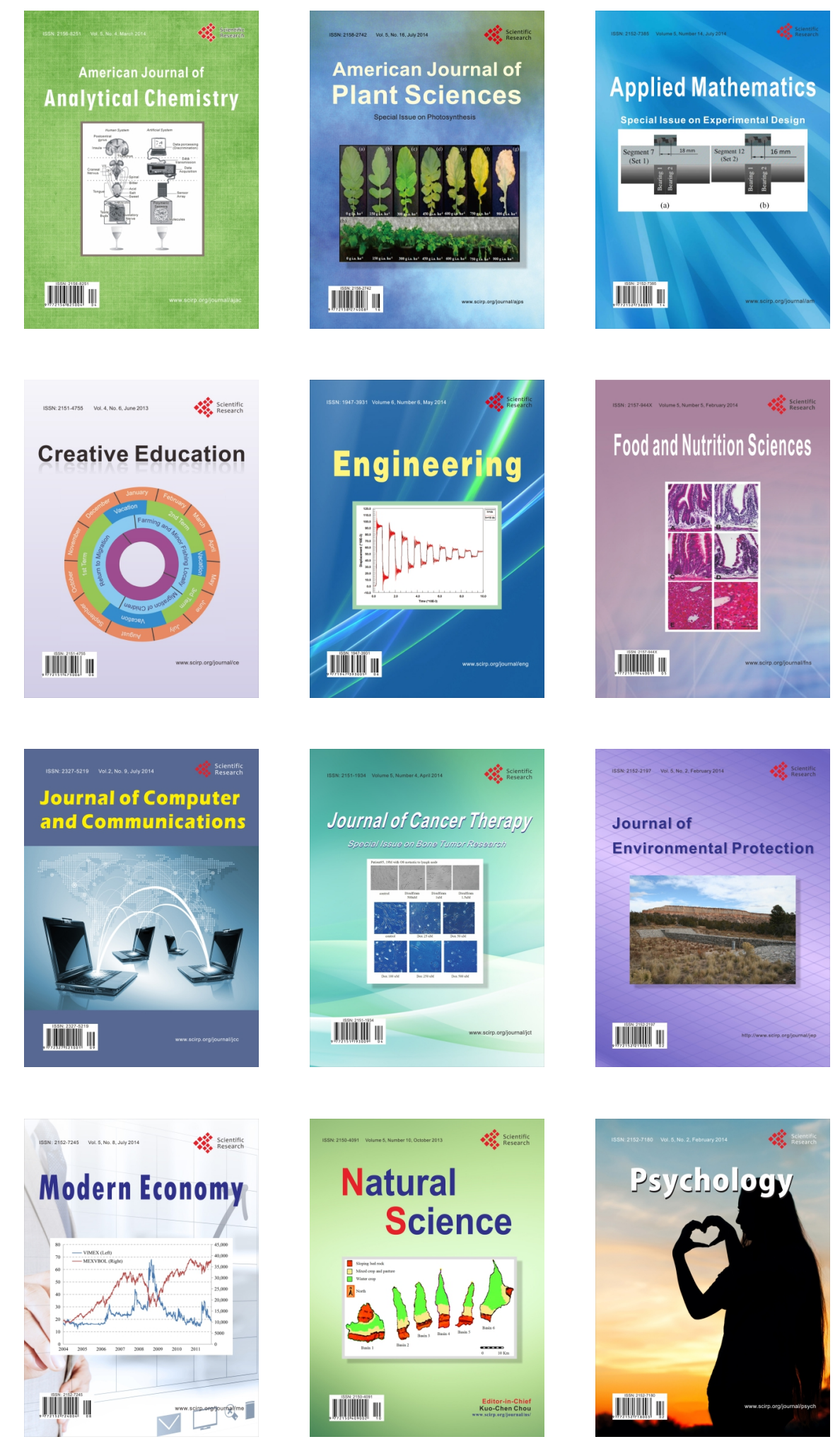